\title{
Pötsimikrobitoimintaa tehostavan erikoisrehun vaikutus lypsylehmien rehunsyöntikykyyn, tuotokseen ja immuunistatukseen
}

\author{
Tuomo Kokkonen ${ }^{1)}$, Siru Salin ${ }^{1)}$, Päivi Nurminen ${ }^{2)}$, Nina Rautonen ${ }^{2)}$, Markku Virkki ${ }^{3)}$ ja Mikko \\ Tuori ${ }^{1)}$ \\ ${ }^{1)}$ Kotieläintieteen laitos, PL 28, 00014 Helsingin yliopisto; etunimi.sukunimi@helsinki.fi \\ ${ }^{2)}$ Danisco Health \& Nutrition, Sokeritehtaantie 20,02460, Kantvik; etunimi.sukunimi@danisco.com \\ ${ }^{3)}$ Suomen Rehu Oy, PL 401,02601 Espoo; Markku.Virkki@suomenrehu.com
}

\section{Tiivistelmä}

Maidon erityksen alkaessa lypsylehmän energian ja ravintoaineiden tarve lisääntyy nopeasti ja lehmä alkaa mobilisoida kudoksistaan rasva- ja aminohappoja. Voimakas kudosmobilisaatio lisää aineenvaihduntasairauksien riskiä. Poikimisen läheisyydessä myös lypsylehmän immuunijärjestelmän toiminta on tilapäisesti heikentynyt.

Tutkimuksen tarkoituksena oli selvittää hiivavalmistetta sisältävän erikoisrehun vaikutusta lypsylehmien rehunsyöntikykyyn, tuotokseen ja immuunistatukseen. Kokeessa oli mukana 12 ensimmäistä kertaa poikivaa ja 12 useammin kuin kaksi kertaa poikinutta lehmää. Koe alkoi kaksi viikkoa ennen poikimista ja kesti 8 viikkoa poikimisen jälkeen. Ennen poikimista lehmät saivat $1,5 \mathrm{~kg} / \mathrm{d}$ täysväkirehua ja $1,5 \mathrm{~kg} / \mathrm{d}$ energiatäydennysrehua sekä säilörehua lasketun tarpeen mukaan. Koeryhmän energiatäydennysrehu (koerehu) sisälsi 1,33\% hiivavalmistetta (Progut, Suomen Rehu Oy). Poikimisen jälkeen vanhempien lehmien väkirehumäärä nostettiin 15 kiloon ja ensikoiden 12 kiloon. Väkirehuannoksessa oli edelleen $1,5 \mathrm{~kg}$ energiatäydennysrehua tai koerehua. Säilörehua annettiin vapaasti.

Rehujen syönnissä, maitotuotoksessa tai maidon pitoisuuksissa ei ollut tilastollisesti merkitseviä ryhmien välisiä eroja poikimisen jälkeen. Ensikoiden keskimääräinen maitotuotos oli $29,1 \mathrm{~kg} / \mathrm{d}$ ja vanhempien lehmien 46,9 kg/d. Ruokinnan ja poikimakerran välillä ei ollut merkitseviä yhdysvaikutuksia. Koeryhmän vanhempien lehmien maidon rasvapitoisuus (45,3 vs. 42,3 g/kg, $\mathrm{P}=0,32$ ) oli kuitenkin numeroarvollisesti suurempi kuin kontrolliryhmän, jolloin vastaavasti myös energiakorjatussa maitotuotoksessa (EKM) oli 5,3\% ero (49,3 vs. $46,8 \mathrm{~kg} / \mathrm{d}, \mathrm{P}=0,20)$.

Elopainon tai kuntoluokan muutoksissa poikimisen jälkeen ei ollut ryhmien välisiä eroja. Koeryhmän vanhempien lehmien plasman NEFA-pitoisuus oli korkeampi kuin kontrolliryhmän $(0,52$ vs. $0,37 \mathrm{mmol} / \mathrm{l}, \mathrm{P}=0,08)$. Ensikoilla vastaavaa eroa ei ollut. Veren asetoasetaatti- ja ureapitoisuuksissa tai valkuaisen hyväksikäytössä maidontuotantoon ei ollut ryhmien välisiä eroja. Kontrolli- ja koeryhmän seerumin IgA-pitoisuuksien välillä ei havaittu eroa. Useamman kerran poikineiden lehmien seerumin IgA-pitoisuudet olivat korkeampia kuin ensikoiden. Toisaalta vanhempien lehmien seerumin IgA-pitoisuus sekä laski jyrkemmin poikimisen jälkeen että alkoi palautua nopeammin verrattuna ensikoihin.

Johtopäätöksenä voidaan todeta, että koerehulla ei ollut tilastollisesti merkitsevää vaikutusta ensikoiden tai vanhempien lehmien rehun syöntiin tai maitotuotokseen. Veren vapaiden rasvahappojen pitoisuus oli kuitenkin suurempi koerehua saaneiden vanhempien lehmien ryhmässä kuin kontrolliryhmässä, mikä pyrki nostamaan maidon rasvapitoisuutta ja EKM-tuotosta koeryhmässä. Vastaavasti koeryhmän vanhempien lehmien EKM-tuotos syötyä kuiva-ainekiloa kohti oli parempi kuin kontrolliryhmän. Vanhempien lehmien seerumin keskimääräinen IgA-pitoisuus oli korkeampi kuin ensikoiden, mutta koe- ja kontrolliryhmän seerumin IgA-pitoisuuksissa ei ollut eroa.

Asiasanat: lypsylehmä, maidontuotanto, hiivavalmiste 


\section{Johdanto}

Erilaisten panimohiivaa (Saccharomyces cerevisiae) sisältävien valmisteiden tai hiivaviljelmistä valmistettujen rehulisäaineiden käyttöä lypsylehmien ruokinnassa on tutkittu varsin paljon. Hiivavalmisteiden lisääminen ruokintaan on lisännyt päivittäistä maitotuotosta useissa tutkimuksissa (Williams ym. 1991, Wohlt ym. 1991, Piva ym. 1993, Wohlt ym. 1998, Robinson ja Garret 1999), mutta monissa tutkimuksissa vaikutusta maitotuotokseen ei ole todettu (Harris ym. 1992, Smith ym. 1993, Dann ym. 2000, Wang ym. 2001). Havaittuihin tuotoksen lisäyksiin on usein liittynyt kuiva-aineen syönnin lisääntyminen (Williams ym. 1991, Piva ym. 1993, Wohlt ym. 1998, Robinson ja Garret 1999). Syönnin lisääntymistä voi selittää sekä kuidun sulavuuden parantuminen (Wohlt ym. 1998, Robinson ja Garret 1999) että ohutsuolesta imeytyvän aminotypen virtauksen lisääntyminen (Erasmus ym. 1992).

Hiivavalmisteiden vaikutukset pötsissä saattavat olla erilaisia riippuen siitä, mitä S. cerevisiae kantaa käytetään (Newbold ym. 1995) sekä siitä, sisältääkö valmiste elävää hiivaa vai ei (Robinson 2005). Sekä eläviä hiivasoluja sisältävien hiivavalmisteiden että hiivaviljelmävalmisteen, jossa ei ole eläviä soluja ja joka sisältää kasvatusalustan, on osoitettu stimuloivan sellulolyyttisten bakteerien kasvua (Newbold ym. 1995, Callaway ja Martin 1997). Molemmat hiivavalmistetyypit ovat myös lisänneet maitohappoa käyttävien bakteerien kasvua ja maitohapon käyttöä (Nisbet ja Martin 1991, Callaway ja Martin 1997). Hiivavalmisteet voivat siis edistää kuidun sulatusta pötsissä lisäämällä sellulolyyttisten bakteerien määrää ja estämällä pötsin pH:n laskua kuidun sulatusta haittaavalle tasolle. Elävien ja ei-elävien hiivavalmisteiden on myös joissakin tutkimuksissa raportoitu lisäävän propionihapon osuutta haihtuvista rasvahapoista (Mutsvangwa ym. 1992, Enjalbert ym. 1999, Sullivan ja Martin 1999) ja lisäävän pötsibakteerien kokonaismäärää (Newbold ym. 1995). Elävää hiivaa sisältävien valmisteiden vaikutus pötsissä voi osittain perustua hiivasolujen kykyyn jatkaa aineenvaihduntaansa pötsissä, vaikka hiivasolut eivät pysty siellä uudistumaan (Kung ym. 1997). Ainakin osittain hiivavalmisteiden kyky stimuloida pötsibakteerien kasvua perustuu niiden sisältämiin ravintoaineisiin, kasvutekijöihin ja provitamiineihin (Newbold ym. 1995, Callaway ja Martin 1997).

Hiivavalmisteita käytetään yksimahaisten eläinten rehuissa antibioottien korvaajina. Hiivojen solunseinämien betaglukaani voi stimuloida immuunijärjestemän toimintaa ja mannoproteiinien on osoitettu estävän haitallisten bakteerien (Escherichia coli, Salmonella spp.) kiinnittymistä suoleen (Graham ja McCracken 2005, Kogan ja Kocher 2007). Hiivavalmisteiden mannaanioligosakkaridit voivat tehostaa lehmän immuunijärjestelmän toimintaa poikimisen läheisyydessä, jolloin immuunipuolustuksen toiminta on luontaisesti heikentynyt, ja ne voivat myös edistää vasikan ternimaidon kautta saaman passiivisen immuniteetin muodostumista (Franklin ym. 2005).

Suurin osa hiivavalmisteiden vaikutusta koskevasta tutkimuksesta on tehty käyttäen maissipohjaista ruokintaa. Tämän tutkimuksen tarkoituksena oli selvittää hiivavalmistetta sisältävän erikoisrehun vaikutusta lypsylehmien rehunsyöntikykyyn, tuotokseen ja immuunistatukseen nurmisäilörehuun perustuvalla ruokinnalla. Tutkimuksessa käytetty hiivavalmiste (Progut, Suomen Rehu Oy) sisältää hydrolysoitua panimohiivaa (S. cerevisiae) ja poikkeaa aiemmissa tutkimuksissa yleisimmin käytetyistä valmisteista siten, että se ei sisällä eläviä hiivasoluja eikä myöskään hiivan kasvualustaa. Valmiste sisältää hiivasolujen nukleotideja sekä solunseinämien betaglukaaneja ja mannoproteiineja. Pötsin olosuhteita simuloivissa in vitro -kokeissa valmiste on lisännyt VFA-tuotantoa ja pötsimikrobien lukumäärää (Vuorenmaa 2006).

\section{Aineisto ja menetelmät}

Tutkimus tehtiin Viikin opetus- ja tutkimustilan navetassa lokakuun 2003 ja huhtikuun 2004 välisenä aikana. Tutkimukseen otettiin 24 lehmää, jotka oli jaettu kahteen ikäryhmään (hiehot ja ennen koetta vähintään kaksi kertaa poikineet). Kummassakin ikäryhmässä eläimet jaettiin poikima-ajan ja elopainon mukaan kuuteen blokkiin ja arvottiin blokkien sisällä eri ruokinnoille (kontrolli, koerehu). Kahden viikon ajan ennen poikimista kaikki lehmät saivat perusväkirehuna täysväkirehua (Krono II, Suomen Rehu Oy) $1,5 \mathrm{~kg} / \mathrm{d}$. Lisäksi lehmät saivat $1,5 \mathrm{~kg} / \mathrm{d}$ energiatäydennysrehua (Acetona Synergy, Suomen Rehu Oy), joka koeryhmällä sisälsi 1,33 \% hiivavalmistetta (Progut). Säilörehua annettiin rajoitetusti siten, että lasketusta energian tarpeesta vähennettiin väkirehusta saatava energia ja loppuosa energian tarpeesta täytettiin säilörehulla.

Poikimisen jälkeen useamman kerran poikineiden lehmien täysi väkirehuannos $(15 \mathrm{~kg} / \mathrm{d})$ saavutettiin 16 päivää poikimisen jälkeen. Ensikoiden väkirehuannos nostettiin kokeen alussa 12 kg:aan päivässä 16 päivän aikana poikimisesta. Koska useilla ensikoilla ilmeni jalkavaivoja, väkirehun 
nostonopeutta hidastettiin kokeen alkuvaiheessa siten, että täysi väkirehuannos $(12 \mathrm{~kg} / \mathrm{d})$ saavutettiin 20 päivän aikana poikimisesta. Lisäksi väkirehun nostonopeutta ensimmäisinä poikimisen jälkeisinä päivinä hidastettiin. Väkirehun nostonopeuden muutokseen mennessä molemmissa ruokintaryhmissä kaksi ensikkoa oli ehtinyt käydä läpi väkirehun nostovaiheen. Lisäksi molemmissa ryhmissä yksi ensikko oli väkirehun nostovaiheessa (enintään viikko poikimisesta).

Poikimisen jälkeen väkirehuannos muodostui täysväkirehusta (Krono II), kontrolli/koerehusta $(1,5 \mathrm{~kg} / \mathrm{d})$ ja valkuaistiivisteestä. Valkuaistiivistettä (Krono-tiiviste, Suomen Rehu Oy) annettiin alkaen 9 d poikimisesta. Valkuaistiivisteen määrä oli vanhemmilla lehmillä $2 \mathrm{~kg} / \mathrm{d}$ ja ensikoilla 1,6 kg/d. Esikuivatun säilörehun saanti oli vapaa poikimisen jälkeen. Kullekin eläimelle annettu rehu ja eläimen tähteeksi jättämä rehu punnittiin päivittäin. Säilörehun vapaa ruokinta varmistettiin pitämällä päivittäinen rehujätemäärä 5 - $10 \%$ :ssa koko rehuannoksesta. Säilörehuista otettiin näyte kerran viikossa ja näytteestä määritettiin kuiva-ainepitoisuus. Viikoittaiset näytteet yhdistettiin rehuanalyysia varten noin kuukauden ajalta. Rehujen keskimääräinen koostumus on esitetty Taulukossa 1.

Taulukko1. Rehujen keskimääräinen koostumus

\begin{tabular}{lccccc}
\hline & Säilörehu & Täysväkirehu & Kontrolli & Koerehu & Valkuaistiiviste \\
\hline Kuiva-aine, g/kg & 288 & 874 & 849 & 875 & 876 \\
Tuhka, g/kg ka & 82 & 68 & 48 & 46 & 79 \\
Raakavalkuainen, g/kg ka & 181 & 182 & 134 & 130 & 321 \\
Raakarasva, g/kg ka & 52 & 53 & 42 & 32 & 87 \\
NDF, g/kg ka & 479 & 271 & 270 & 278 & 116 \\
ADF, g/kg ka & 274 & 111 & 109 & 340 & 65 \\
Tärkkelys, g/kg ka & 0,91 & 339 & 335 & & \\
RY/kg ka & 84 & & & \\
OIV, g/kg ka & 37 & & & \\
PVT, g/kg ka & & &
\end{tabular}

Maitotuotos mitattiin joka lypsykerralta. Maitonäytteitä otettiin 1, 2, 4, 6 ja 8 viikkoa poikimisesta. Näytteistä määritettiin rasva-, valkuais-, laktoosi- ja ureapitoisuudet sekä solujen lukumäärä. Lehmät punnittiin kaksi viikkoa ennen poikimista, ja poikimisen jälkeen $1 \mathrm{~d}$ (12 - 36 tuntia poikimisesta), 3 ja 7 päivää sekä 2, 4, 6 ja 8 viikkoa poikimisesta. Lehmät kuntoluokitettiin kaksi viikkoa ennen poikimista, poikimisen jälkeen ja sitten kahden viikon välein. Kunkin lehmän keskimääräinen viikottainen energiakorjattu maitotuotos sekä rasva-, valkuais- ja laktoosituotos on laskettu käyttäen viikon keskimääräistä maitotuotosta ja ko. viikolla määritettyä maidon koostumusta. Viikoille 3, 5 ja 7, jolloin maitonäytteitä ei otettu, on käytetty edellisen viikon maidon pitoisuuksia.

Verinäytteitä otettiin kaksi viikkoa ennen poikimista, poikimisen jälkeen 1 päivän kuluttua (1236 tuntia poikimisesta) sekä jälkeen 2,4 ja $8( \pm 1 \mathrm{~d}$ toleranssi) viikkoa poikimisesta. Näytteet otettiin häntäsuonesta ennen iltapäiväruokintaa.

Syönti- ja maitotuotostulokset, energian ja valkuaisen saanti ja hyväksikäyttö sekä poikimisen jälkeen otettujen verinäytteiden tulokset analysoitiin toistettujen mittausten mallilla SASin (versio 9.1) Mixed-proseduuria käyttäen. Kiinteinä tekijöinä mallissa olivat ruokinnan, poikimakerran ja ajan vaikutukset sekä yhdysvaikutukset ruokinta*poikimakerta, ruokinta*aika, poikimakerta*aika ja ruokinta*poikimakerta*aika. Lohkon vaikutus poikimakerran sisällä ja sen yhdysvaikutus ajan kanssa olivat mukana mallissa satunnaisina tekijöinä. Aika viittaa laktaatioviikkoon syönti-, maitotuotos- ja hyväksikäyttötuloksissa ja näytteenottoajankohtaan (päivää poikimisesta) verinäytetuloksissa. Kunkin lehmän havaintoihin sovitettiin kolme eri kovaranssirakennetta: CS, UN ja AR(1). Kunkin muuttujan kohdalla valittiin pienimmän Bayesian Information Criterion -arvon antaneen kovarianssimallin tulokset. Maidon koostumusaineistoa ja verinäytetuloksia analysoitaessa AR(1)-kovarianssirakenteen sijasta käytettiin kuitenkin SP(POW)-kovarianssirakennetta, koska näytekertojen välit eivät olleet yhtä pitkiä.

Maidon soluluku ja veren NEFA- ja asetikkahappopitoisuudet eivät olleet normaalisti jakautuneita. Maidon soluku ja veren NEFA-pitoisuudet analysoitiin logaritmimuunnoksen jälkeen toistettujen mittausten mallilla. Veren asetetikkahappopitoisuudet on analysoitu näytekerroittain Friedmanin 
kaksisuuntaisella ei-parametrisella varianssianalyysilla. Koetta edeltävien verinäytteiden pitoisuudet sekä elopainon ja kuntoluokan muutokset analysoitiin SASin Mixed-proseduurilla. Mallissa oli kiinteinä tekijöinä ruokinnan ja poikimakerran vaikutukset sekä niiden yhdysvaikutus ja satunnaistekijänä lohkon vaikutus poikimakerran sisällä.

Taulukoissa esitetyt keskiarvot ovat pienimmän neliösumman keskiarvoja ja kuvissa esitetyt aritmeettisia keskiarvoja.

\section{Tulokset ja tulosten tarkastelu}

Koe- ja kontrolliyhmien välillä ei ollut eroja säilörehun kuiva-aineen syönnissä tai kuiva-aineen kokonaissyönnissä (Taulukko 2). Näin ollen myöskään ravintoaineiden tai muuntokelpoisen energian (ME) saannissa ei ollut eroja. Ruokinnan ja poikimakerran välillä ei ollut merkitsevää yhdysvaikutusta. Ensikot söivät keskimäärin noin $1,4 \mathrm{~kg}$ ka/d vähemmän säilörehua kuin vanhemmat lehmät. Kun ensikoiden väkirehuannos oli pienempi ja sitä lisättiin poikimisen jälkeen hitaammin kuin vanhemmilla lehmillä, aika*poikimakerta yhdysvaikutus oli tilastollisesti merkitsevä raakavalkuaisen, raakarasvan, ME:n ja OIV:n saannissa. Ajan ja ruokinnan yhdysvaikutukset eivät olleet tilastollisesti merkitseviä.

Koko aineiston perusteella tarkasteltuna maitotuotoksessa tai maidon pitoisuuksissa ei ollut tilastollisesti merkitseviä ryhmien välisiä eroja (Taulukko 2). Ensikoiden maito- ja valkuaistuotos nousivat poikimisen jälkeen hitaammin kuin vanhempien lehmien ja ensikoiden maidon valkuaispitoisuus väheni poikimisen jälkeen hitaammin kuin vanhempien lehmien. Logaritmimuunnettu maidon soluluku oli suurempi ensikoilla kuin vanhemmilla lehmillä.

Vaikka ruokinnan ja poikimakerran yhdysvaikutukset eivät olleet tilastollisesti merkitseviä, koerehua saaneiden vanhempien lehmien maidon rasvapitoisuus ja EKM- ja rasvatuotokset olivat numeroarvollisesti suurempia kuin kontrolliryhmän. Kun tilastollinen analyysi rajattiin pelkästään vanhempiin lehmiin, vanhempien lehmien EKM-tuotoksen ero oli 5,3\% (49,3 vs. 46,8 kg/d, P=0,20). Robinsonin ja Erasmuksen (2007) analyysissa 21 kokeen perusteella laskettu hiivavalmisteiden keskimääräinen maidon energian tuotosvaste oli 3,1\%. Heidän aineistossaan suuri osa kokeista on tehty käyttäen eläviä hiivavalmisteita, kun taas tässä kokeessa tutkittu tuote ei sisällä elävää hiivaa. Robinsonin ja Erasmuksen (2007) analyysissa elävien ja ei-elävien hiivavalmisteiden tuotosvaste oli samanlainen.

Elopainon muutoksissa poikimisesta kokeen loppuun ei ollut tilastollisesti merkitseviä ryhmien välisiä eroja. Kontrolliryhmän vanhempien lehmien elopainon muutos oli $-36 \mathrm{~kg}$ ja koeryhmän -31 $\mathrm{kg}$. Ensikoiden elopainon muutokset olivat vastaavasti kontrolliryhmässä $-17 \mathrm{~kg}$ ja koeryhmässä +4 kg. Kontrolli- ja koeryhmien kuntoluokkien muutos oli samanlainen. Ensikot menettivät kokeen aikana keskimäärin noin 0.4 kuntoluokkayksikköä ja vanhemmat lehmät noin 0,8 yksikköä.

Vanhempien lehmien plasman NEFA-pitoisuus oli koko kokeen korkeampi, mutta laski poikimisen jälkeen jyrkemmin kuin ensikoiden plasman NEFA-pitoisuus. Koeryhmän vanhempien lehmien plasman NEFA-pitoisuus oli korkeampi kuin kontrolliryhmän ( 0,52 vs. $0,37 \mathrm{mmol} / \mathrm{l}, \mathrm{P}=0,08$ ) (Taulukko 3). Ensikoilla vastaavaa eroa ei ollut (keskimäärin 0,24 mmol/l). Koeryhmän plasman NEFApitoisuus oli heti poikimisen jälkeen korkeampi kuin kontrolliryhmän, mutta laski kokeen loppuun mennessä samalle tasolle (Kuva 1A).

Koeryhmän vanhempien lehmien korkeampi plasman NEFA-pitoisuus viittaa siihen, että lisääntyneen EKM-tuotoksen vaatima energia tuli osittain rasvakudoksen mobilisaatiosta, vaikka elopainon ja kuntoluokan muutokset eivät tätä tuekaan. Elopainon muutos ei ole luotettava kudosmobilisaation indikaattori tuotoskauden alussa, jolloin ruoansulatuskanavan sisällön painossa ja kudosten vesipitoisuudessa tapahtuu huomattavia muutoksia (Sutter ja Beever 2000). Kuntoluokituksen käyttökelpoisuutta koeryhmien välisten erojen tarkastelussa heikentää kuntoluokka-arvioiden subjektiivisuus. Lisäksi kuntoluokituksella ei pystytä luotettavasti havaitsemaan pieniä (enintään 0,25 yksikköä) kuntoluokan muutoksia (Schröder ja Stauffenbiel 2006). Sen sijaan maidon rasvapitoisuuden numeroarvollinen nousu $(45,3$ vs. $42,3 \mathrm{~g} / \mathrm{kg}, \mathrm{P}=0,32)$ viittaa myös rasvakudoksen mobilisaation osuuteen, koska tuotoskauden alussa huomattava osa maidon rasvahapoista on peräisin rasvakudoksesta. Useista aiemmista tutkimuksista (Williams ym. 1991, Piva ym. 1993, Wohlt ym. 1998, Robinson ja Garret 1999) poiketen hiivavalmisteen positiivinen vaikutus maitotuotokseen ei siis ollut yhteydessä kuivaaineen syönnin lisääntymiseen, vaan koeryhmän vanhemmat lehmät tuottivat enemmän maitoa syötyä kuiva-ainekiloa kohti (2,29 vs. $2,15 \mathrm{~kg}$ EKM / kg ka, P=0,08). Hiivavalmisteen tuotosvaste saattaa olla yhteydessä parantuneeseen kuidun sulatukseen (Erasmus ym. 1992, Wohlt ym. 1998) tai se on saattanut parantaa muuntokelpoisen energian hyväksikäyttöä maidon tuotantoon ohutsuolesta imeytyvän 
valkuaisen saannin lisääntyessä. Tämän kokeen perusteella näiden tekijöiden osuutta ei kuitenkaan pystytä arvioimaan.
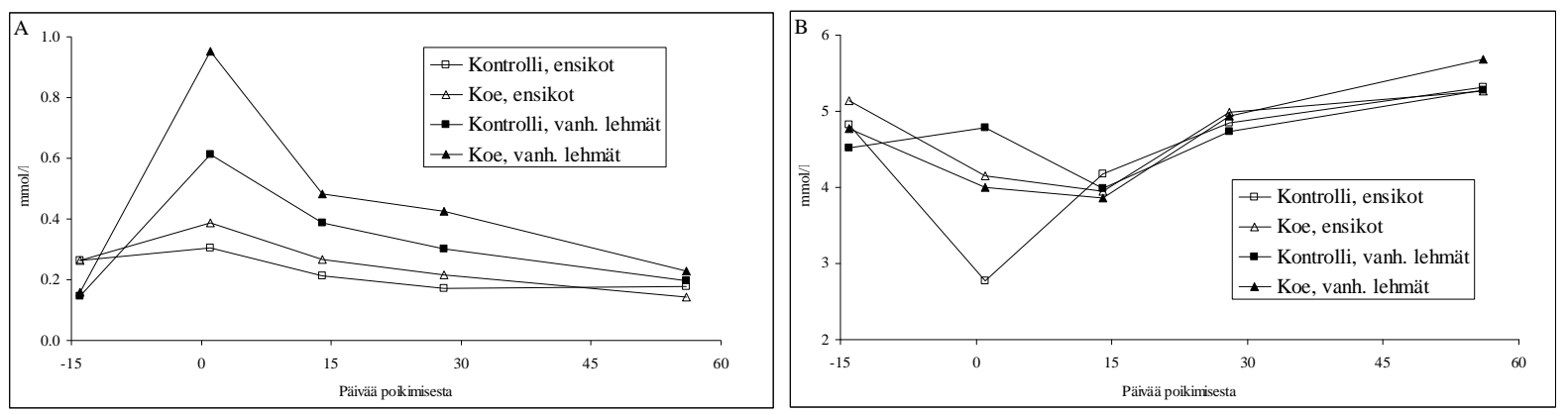

Kuva 1. Plasman (A) NEFA- ja (B) ureapitoisuudet
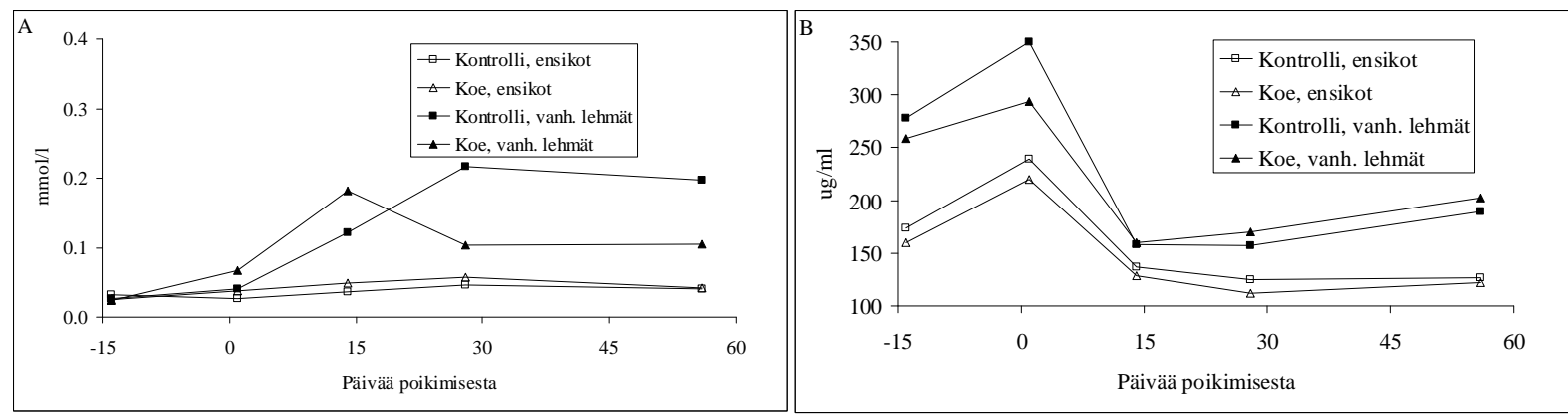

Kuva 2. Veren (A) asetoasetaatti- ja seerumin (B) IgA-pitoisuudet

Plasman ureapitoisuuksissa ei ollut merkitseviä ryhmien välisiä eroja, yhtäpitävästi aiempien tutkimusten kanssa (Taulukko 3) (Smith ym. 1993, Dann ym. 2000). Useilla kontrolliryhmän ensikoilla oli heti poikimisen jälkeen matala ja kahdella kontrolliryhmän vanhemmalla lehmällä korkea plasman ureapitoisuus, josta syystä aika*ruokinta*poikimakerta yhdysvaikutus oli merkitsevä (Kuva 1B). Veren asetoasetaattipitoisuuksien erot eivät olleet tilastollisesti merkitseviä (Kuva 2A). Myöskään seerumin keskimääräisissä IgA-pitoisuuksissa poikimisen jälkeen ei ollut koeryhmien välisiä eroja (Taulukko 3). Koska kokeen alkua edeltävät IgA-pitoisuudet olivat numeroarvollisesti erilaiset koe- ja kontrolliryhmässä, poikimisen jälkeiset pitoisuudet testattiin myös käyttäen kovariaattina pitoisuutta ennen kokeen alkua. Kovariaatin käyttö pienensi huomattavasti keskiarvon keskivirhettä (SEM), mutta ei muuttanut ruokintaryhmien tai poikimakertojen keskiarvojen keskinäistä suhdetta. Tämän kokeen tulosten kanssa yhtäpitävästi Franklinin ym. (2005) tutkimuksessa $10 \mathrm{~g} / \mathrm{d}$ mannaanioligosakkarideja ei vaikuttanut lehmien seerumin IgA-, IgG- tai IgM-pitoisuuksiin tiineyden viimeisen kuukauden aikana tai heti poikimisen jälkeen. Vanhempien lehmien seerumin keskimääräinen IgA-pitoisuus oli korkeampi kuin ensikoiden $(\mathrm{P}<0,10)$ ja poikimakerran vaikutus oli pienimmillään noin kaksi viikkoa poikimisen jälkeen (aika*poikimakerta, $\mathrm{P}<0,05$ ). Siten vanhempien lehmien seerumin IgA -pitoisuus suhteellisesti sekä laski jyrkemmin poikimisen jälkeen että alkoi palautua nopeammin verrattuna ensikoihin (Kuva 2B).

\section{Johtopäätökset}

Koerehulla ei ollut tilastollisesti merkitsevää vaikutusta ensikoiden tai vanhempien lehmien rehun syöntiin tai maitotuotokseen. Veren vapaiden rasvahappojen pitoisuus oli kuitenkin suurempi koerehua saaneiden vanhempien lehmien ryhmässä kuin kontrolliryhmässä, mikä pyrki nostamaan maidon rasvapitoisuutta ja EKM-tuotosta koeryhmässä. Vastaavasti koeryhmän vanhempien lehmien EKMtuotos syötyä kuiva-ainekiloa kohti oli parempi kuin kontrolliryhmän. Vanhempien lehmien seerumin keskimääräinen IgA-pitoisuus oli korkeampi kuin ensikoiden, mutta koe- ja kontrolliryhmän keskimääräisissä seerumin IgA-pitoisuuksissa ei ollut eroa. Myöskään veren asetoasetaattipitoisuuksissa ei ollut koe- ja kontrolliryhmän välillä eroa. 


\section{Kirjallisuus}

Callaway, E.S. \& Martin, S.A. 1997. Effects of Saccharomyces cerevisiae culture on ruminal bacteria that utilize lactate and digest cellulose. J. Dairy Sci. 80:2035-2044.

Dann, H.M., Drackley, J.K., McCoy, G.C., Hutjens, M.F. \& Garrett, J.E. 2000. Effects of yeast culture (Saccharomyces cerevisiae) on prepartum intake and postpartum intake and milk production of Jersey cows J. Dairy Sci. 83: 123-127.

Enjalbert, F., Garrett, J.E., Moncoulon, R., Bayourthe, C. \& Chicoteau, P. 1999. Effects of yeast culture (Saccharomyces cerevisiae) on ruminal digestion in non-lactating dairy cows. Anim. Feed Sci. Technol. 76: 195206.

Erasmus, L.J., Botha, P.M. \& Kistner, A. 1992. Effect of yeast culture supplement on production, rumen fermentation, and duodenal nitrogen flow in dairy cows. J. Dairy Sci. 75: 3056-3065.

Franklin, S.T., Newman, M.C., Newman, K.E. \& Meek, K.I. 2005. Immune parameters of dry cows fed mannan oligosaccharide and subsequent transfer of immunity to calves. J. Dairy Sci. 88: 766-775.

Graham, H \& McCracken, K. 2005. Yeasts in animal feeds. Teoksessa: Garnsworthy, P.C. \& Wiseman, J. (toim.) Recent advances in animal nutrition 2005. Nottingham University Press, s. 169-211.

Kogan, G. \& Kocher, A. 2007. Role of yeast cell wall polysaccharides in pig nutrition and health protection. Livest. Sci. 109: 161-165.

Kung, Jr., L.E., Kreck, M. \& Tung, R.S. 1997. Effects of a live yeast culture and enzymes on in vitro ruminal fermentation and milk production of dairy cows. J. Dairy Sci. 80:2045-2051.

Mutsvangwa, T., Edwards, I.E., Topps, J.H. \& Paterson, G.F.M. 1992. The effect of dietary inclusion of yeast culture (Yea-Sacc) on patterns of rumen fermentation, food intake and growth of intensively fed bulls. Anim. Prod. 55: 35-41.

Newbold, C. J., Wallace, R.J. \& McIntosh, F.M. 1995. Different strains of Saccharomyces cerevisiae differ in their effects on ruminal bacterial numbers in vitro and in sheep. J. Anim. Sci. 73: 1811-1818.

Nisbet, D.J. \& Martin, S.A. 1991. Effect of a Saccharomyces cerevisiae culture on lactate utilization by the ruminal bacterium Selenomonas ruminantium. J. Anim. Sci. 69: 4628-4633.

Piva, G., Belladonna, S., Fusconi, G., \& Sicbaldi, F. 1993. Effects of yeast on dairy cow performance, ruminal fermentation, blood components, and milk manufacturing properties. J. Dairy Sci. 76: 2717-2722.

Robinson, P.H. 2005. Yeast products for growing and lactating dairy cattle: Impacts on rumen fermentation and performance. URL=http://animalscience.ucdavis.edu/faculty/robinson/Articles/FullText/pdf/Web200501.pdf. Viitattu 27.11.2007.

Robinson, P.H. \& Erasmus, L.J. 2007. Lactating dairy cow responses to yeast products. J. Anim. Sci. 85 (Suppl. 1): Abstr. 362.

Robinson, P.H. \& Garrett, J.E. 1999. Effect of yeast culture (Saccharomyces cerevisiae) on adaptation of cows to postpartum diets and on lactational performance. J. Anim. Sci. 77: 988-999.

Schröder, U.J. \& Stauffenbiel, R. 2006. Invited review: Methods to determine body fat reserves in the dairy cow with special regard to ultrasonographic measurement of backfat thickness. J. Dairy Sci. 89: 1-14.

Smith, W.A., Harris, Jr., B., Van Horn, H.H. \& Wilcox, C. J. 1993. Effects of forage type on production of dairy cows supplemented with whole cottonseed, tallow, and yeast. J. Dairy Sci. 76: 205-215.

Sullivan, H.M. \& Martin, S.A. 1999. Effects of Saccharomyces cerevisiae culture on in vitro mixed ruminal microorganism fermentation. J. Dairy Sci. 82: 2011-2016.

Sutter, F. \& Beever, D.E. 2000. Energy and nitrogen metabolism in Holstein-Friesian cows during early lactation. Anim. Sci. 70: 503-514.

Vuorenmaa, J. 2006. Hydrolysed brewery yeast for dairy cows. International Dairy Topics 6: 19-21.

Wang, Z., Eastridge, M.L. \& Qiu, X. 2001. Effects of forage neutral detergent fiber and yeast culture on performance of cows during early lactation. J. Dairy Sci. 84: 204-212.

Williams, P.E.V., Tait, C.A.G., Innes, G.M. \& Newbold, C.J. 1991. Effects of the inclusion of yeast culture (Saccharomyces cervisiae plus growth medium) in the diet of dairy cows on milk yield and forage degradation and fermentation patterns in rumen of steers. J. Anim. Sci. 69: 3016-3026.

Wohlt, J.E., Finklestein, A.D. \& Chung, C.H. 1991. Yeast culture to improve intake, nutrient digestibility, and performance by dairy cattle during early lactation. J. Dairy Sci. 74: 1395-1400.

Wohlt, J.E., Corcione, T.T. \& Zajac, P.K. 1998. Effect of yeast on feed intake and performance of cows fed diets based on corn silage during early lactation. J. Dairy Sci. 81: 1345-1352. 
Taulukko 2. Maitotuotos ja rehujen syönti, viikot $1-8$

\begin{tabular}{|c|c|c|c|c|c|c|c|c|c|c|c|}
\hline & \multicolumn{2}{|l|}{ Ensikot } & \multicolumn{2}{|c|}{ Vanhemmat lehmät } & \multirow[b]{2}{*}{ SEM } & \multicolumn{2}{|c|}{ Merkitsevyys } & \multirow[b]{2}{*}{$\begin{array}{l}\text { Ruokinta* } \\
\text { poikimakerta }\end{array}$} & \multirow[b]{2}{*}{ Aika } & \multirow[b]{2}{*}{$\begin{array}{l}\text { Aika* } \\
\text { ruokinta }\end{array}$} & \multirow[b]{2}{*}{$\begin{array}{l}\text { Aika* } \\
\text { poikimakerta }\end{array}$} \\
\hline & Kontrolli & Koerehu & Kontrolli & Koerehu & & Ruokinta & Poikimakerta & & & & \\
\hline Maitoa, kg/d & 29,1 & 29,0 & 46,5 & 47,3 & 1,43 & & $* * *$ & & $* * *$ & & $* *$ \\
\hline $\mathrm{EKM}, \mathrm{kg} / \mathrm{d}$ & 31,3 & 30,6 & 46,8 & 49,3 & 1,30 & & $* * *$ & & $* * *$ & & \\
\hline Rasvapitoisuus, g/kg & 45,2 & 43,6 & 42,3 & 45,3 & 2,00 & & & & $* * *$ & & \\
\hline Valkuaispit., g/kg & 35,5 & 34,3 & 33,9 & 33,3 & 0,78 & & & & $* * *$ & & $* *$ \\
\hline Laktoosipit., g/kg & 49,2 & 49,8 & 46,7 & 46,7 & 0,57 & & $* *$ & & $* * *$ & & \\
\hline Ureapitoisuus, g/dl & 32 & 31 & 28 & 28 & 1,2 & & $*$ & & $* * *$ & & \\
\hline Log (solut) & 1,97 & 1,96 & 1,46 & 1,51 & 0,152 & & $*$ & & o & & \\
\hline Rasvatuotos, g/d & 1290 & 1248 & 1899 & 2087 & 77,2 & & $* * *$ & & $* * *$ & & \\
\hline Valkuaistuotos, $\mathrm{g} / \mathrm{d}$ & 1015 & 983 & 1537 & 1541 & 34,4 & & $* * *$ & & $* * *$ & & $*$ \\
\hline Säilörehua, kg ka/d & 8,3 & 8,5 & 9,8 & 9,8 & 0,44 & & $*$ & & $* *$ & & \\
\hline Väkirehua, kg ka/d & 9,6 & 9,7 & 12,1 & 12,2 & 0,07 & & & & & & \\
\hline Kuiva-ainetta, kg/d & 17,9 & 18,2 & 21,9 & 21,9 & 0,42 & & $* * *$ & & $* * *$ & & o \\
\hline Raakavalkuaista, g/d & 3356 & 3363 & 4133 & 4156 & 101,6 & & $* * *$ & & $* * *$ & & $*$ \\
\hline Raakarasvaa, g/d & 962 & 957 & 1181 & 1166 & 20,8 & & $* * *$ & & $* * *$ & & $*$ \\
\hline NDF, g/d & 4946 & 5112 & 5749 & 5814 & 225,8 & & $* *$ & & $* * *$ & & \\
\hline $\mathrm{ADF}, \mathrm{g} / \mathrm{d}$ & 3404 & 3484 & 4036 & 4083 & 130,1 & & $* * *$ & & $* * *$ & & \\
\hline $\mathrm{ME}, \mathrm{MJ} / \mathrm{d}$ & 212 & 214 & 259 & 261 & 5,3 & & $* * *$ & & $* * *$ & & $* *$ \\
\hline OIV, g/d & 1792 & 1811 & 2207 & 2218 & 40,2 & & $* * *$ & & $* * *$ & & $* *$ \\
\hline EKM/ka-syönti, kg/kg & 1,75 & 1,69 & 2,15 & 2,29 & 0,081 & & $* * *$ & & $*$ & & $* * *$ \\
\hline Valk. tuotos/rv-saanti, g/g & 0,31 & 0,30 & 0,38 & 0,38 & 0,013 & & $* * *$ & & $* * *$ & & $* * *$ \\
\hline
\end{tabular}

Taulukko 3. Veriarvot poikimisen jälkeen

\begin{tabular}{|c|c|c|c|c|c|c|c|c|c|c|c|}
\hline & \multicolumn{2}{|l|}{ Ensikot } & \multicolumn{2}{|c|}{ Vanhemmat lehmät } & \multirow[b]{2}{*}{ SEM } & \multicolumn{2}{|c|}{ Merkitsevyys } & \multirow[b]{2}{*}{$\begin{array}{l}\text { Ruokinta* } \\
\text { poikimakerta }\end{array}$} & \multirow[b]{2}{*}{ Aika } & \multirow[b]{2}{*}{$\begin{array}{l}\text { Aika* } \\
\text { ruokinta }\end{array}$} & \multirow[b]{2}{*}{$\begin{array}{l}\text { Aika* } \\
\text { poikimakerta }\end{array}$} \\
\hline & Kontrolli & Koerehu & Kontrolli & Koerehu & & Ruokinta & Poikimakerta & & & & \\
\hline NEFA, mmol/l & 0,22 & 0,25 & 0,37 & 0,52 & 0,032 & $*$ & $* * *$ & 0 & $* * *$ & & $* * *$ \\
\hline Urea, mmol/1 & 4,28 & 4,59 & 4,70 & 4,62 & 0,314 & & & & $* * *$ & & 1 \\
\hline $\mathrm{IgA}, \mu \mathrm{g} / \mathrm{ml}$ & 157 & 146 & 210 & 206 & 36,2 & & o & & $* * *$ & & $*$ \\
\hline IgA korjattu, $\mu \mathrm{g} / \mathrm{ml}^{2}$ & 164 & 173 & 192 & 193 & 8,5 & & $\mathrm{O}$ & & $* * *$ & & $*$ \\
\hline
\end{tabular}

${ }^{1}$ Ruokinta*poikimakerta*aika: $\mathrm{P}=0.01 ;{ }^{2}$ Kovariaattina ennen koetta mitattu pitoisuus 